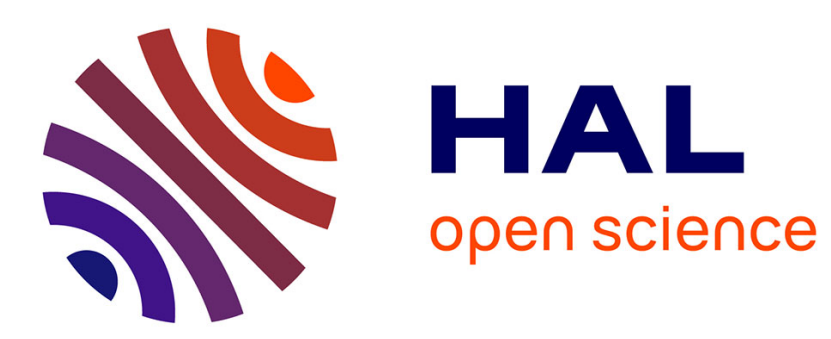

\title{
Budgetary constraints and programmatic choices by Flemish subsidized theatres
}

Kristien Werck, Mona Grinwis Plaat Stultjes, Bruno Heyndels

\section{To cite this version:}

Kristien Werck, Mona Grinwis Plaat Stultjes, Bruno Heyndels. Budgetary constraints and programmatic choices by Flemish subsidized theatres. Applied Economics, 2008, 40 (18), pp.2369-2379. 10.1080/00036840600970153 . hal-00581977

\section{HAL Id: hal-00581977 \\ https://hal.science/hal-00581977}

Submitted on 1 Apr 2011

HAL is a multi-disciplinary open access archive for the deposit and dissemination of scientific research documents, whether they are published or not. The documents may come from teaching and research institutions in France or abroad, or from public or private research centers.
L'archive ouverte pluridisciplinaire HAL, est destinée au dépôt et à la diffusion de documents scientifiques de niveau recherche, publiés ou non, émanant des établissements d'enseignement et de recherche français ou étrangers, des laboratoires publics ou privés. 


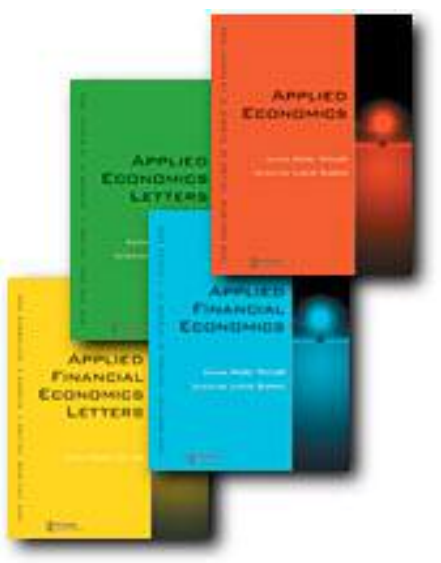

Budgetary constraints and programmatic choices by Flemish subsidized theatres

\begin{tabular}{|r|l|}
\hline Journal: & Applied Economics \\
\hline Manuscript ID: & APE-05-0465.R1 \\
\hline Journal Selection: & Applied Economics \\
\hline JEL Code: & $\begin{array}{l}\text { L31 - Nonprofit Institutions }<\text { L3 - Nonprofit Organizations and } \\
\text { Public Enterprise }<\text { L - Industrial Organization }\end{array}$ \\
\hline Keywords: & theatre, subsidies, programmatic choices \\
\hline
\end{tabular}

Manuscript Central $^{\text {powers by ScholarOne }}$ 


\title{
Budgetary constraints and programmatic choices by Flemish subsidized theatres
}

\author{
Kristien WERCK, \\ Mona GRINWIS PLAAT STULTJES \\ \& Bruno HEYNDELS \\ Vrije Universiteit Brussel
}

\begin{abstract}
We analyse programmatic choices of Flemish theatres and examine how they are affected by the theatres' budgetary situation. Following Lancaster's characteristics approach, we identify several output characteristics of individual Flemish theatres during the period 1980-2000. A simultaneous equation approach is used to capture the theatre managers', subsidizing government's and consumers' behaviour. We find that changes in the budgetary situation of a theatre are translated into changes of both the 'amount' and the nature of the theatre's output. The budgetary impact on artistic choices has intensified since the introduction of a 4-yearly instead of yearly allocation of subsidies. The decrease in financial risk for the individual theatres leads to an increase in artistic risk-taking.
\end{abstract}

Key words: $\quad$ programmatic choices, theatre, subsidies

JEL: $\quad$ Z11

\author{
Corresponding author: \\ Kristien Werck \\ Vrije Universiteit Brussel \\ Department of Economics - 2C137 \\ Pleinlaan 2 \\ B-1050 Brussels, Belgium \\ Tel. +32 (0)2/629.14.20 \\ Fax +32 (0)2/629.20.60 \\ E-mail: Kristien.Werck@vub.ac.be
}




\section{Introduction}

Like any other firm, a theatre needs money. Artistic productions can be presented to the audience only when sufficient budgetary means are available. Broadly speaking, theatres rely on both the market (through ticket sales, sponsoring, ...) and subsidizing governments to soften this constraint. But popular or corporate support may increase or decrease, subsidies may be augmented or cut back. For the theatre directors this means that the budgetary constraint loosens or tightens and action has to be undertaken. Programmatic choices adjusting the theatrical output are a prime instrument for the theatre management. It can adapt the number of performances or productions to the new budgetary situation or it can change the nature of the theatre's output. These types of reactions are the focus of the present analysis. More specifically, we examine how budgetary constraints affect the programmatic choices made by Flemish theatres.

The program of a performing arts organisation can be seen as the result of an economic optimisation process (Frey and Pommerehne, 1990). The decision-maker, making programmatic choices, pursues certain objectives. A discussion on the objectives of managers in the non-profit performing arts is in Section 2. Full realisation of these objectives is confined by budgetary constraints. Section 3 reviews the literature on the impact of budgetary changes on artistic programming. Section 4 uses a panel of Flemish theatres (1980-2000) to analyse how budgetary changes affect programmatic choices. We account explicitly for the heterogeneity of theatre output: programming corresponds to selecting a Lancasterian set of characteristics. A simultaneous equation approach is used also incorporating the behaviour of consumers and of the subsidizing government. A conclusion is in Section 5. 


\section{Objectives of (non-profit) theatre managers}

A theatre manager making programmatic choices will - in most general terms maximise his/her utility under a set of constraints. Most economic models of nonprofit performing arts organisations assume that theatre managers are biased towards the maximization of artistic quality (Krebs and Pommerehne, 1995). The pursuit of quality can take many forms. A theatre director could opt for quality by programming innovative, less popular works that appeal only to the most 'refined' tastes. Quality could also be achieved by making the production of any work as impressive as possible, for example by a virtuoso performance, by lavish stage sets or costumes (Hansmann, 1981).

Although the quality objective dominates in the literature, alternatives have been suggested. First, a theatre director could maximise audience size e.g. to spread culture to a broad segment of the population (Caves, 2000). There may be a trade-off: a 'highbrow' (high quality) program may decrease audience sizes (Krebs and Pommerehne, 1995). Other alternatives to quality maximization are budget maximization (Hansmann, 1981, 347) ${ }^{1}$, acquiring legitimacy of the organisation (DiMaggio, 1987) or maximisation of the theatre manager's standing among his peers (Krebs and Pommerehne, 1995). The latter objective may reflect the existence of agency problems (Du Bois et al., 2004).

\footnotetext{
${ }^{1}$ His approach is in line with Niskanen's description of the budget maximising bureaucracy (Niskanen, 1971). Note that non-profit theatres are a particular example of a bureaucracy according to Niskanen's definition of bureaus as "non-profit organisations which are financed, at least in part, by a periodic appropriation or grant" (Niskanen, 1971).
} 


\section{Decision-making in the performing arts}

A theatre manager faces constraints imposed by the 'artistic technology' and the budget. The latter is typically composed of three parts: the public's contribution in the form of ticket sales, corporate sponsoring and public subsidies. Changes in the technology, prices of inputs and/or the budget can be expected to lead to other programmatic choices. The cultural economics literature has focused on two issues: the impact of subsidy on output and the effect of increasing costs (input prices) on the performing arts in general.

Several empirical studies examine the effect of government subsidy on one particular aspect of theatrical output, namely the extent to which the repertoire is diverse or innovative. The general assumption is that government support - as opposed to box office revenues or private donations - enhances artistic freedom and the possibility to experiment. Martorella (1975) gives the example of the Metropolitan and Lyric Opera of Chicago. These depend heavily on box office revenues. Their programming turns out to be 'conservative'. In contrast, the New York City Opera that has been subsidized by the National Council of the Arts and the Ford Foundation, has been able to commission new works and present avant-garde or rarely performed operas. Heilbrun (2001) suggests that the increasing diversity in the Canadian opera repertoire (as compared to decreasing diversity in the U.S.) is explained by the higher levels of public support. Pierce (2000) examines how variations in funding sources affect 'program conventionality' of U.S. opera companies. 'Conventionality' refers to the extent to which the program of an organisation is similar to the programs of other organisations. Local government funding significantly increases conventionality. A probable reason is that local politicians need to support programs that are popular. 
The opposite effect was found for support from the National Endowment for the Arts: it decreases the conventionality of opera programming.

Theatre studies largely support the hypothesis that public support increases diversity. Austen-Smith (1980) finds that subsidy encourages the presentation of minority interest plays in English provincial repertory theatres. In their study of American resident theatres, DiMaggio and Stenberg (1985) show how a higher dependence on the market is associated with a greater conformity of repertoire. In a study on English theatres, O'Hagan and Neligan (2005) find a negative relationship between subsidy as a proportion of total income and the conventionality of theatre programs.

Baumol and Baumol (1985b) analyse the effect of ever-increasing costs on the output of performing arts organisations. Their concept of the 'suppressed cost disease' is the less well-known brother of Baumol's cost disease. The intuition behind the latter is simple: (a) the labour intensive performing arts sector does not benefit from technological progress as much as other sectors and (b) the tendency for wages in the arts sector to follow wages elsewhere leads to ever-increasing costs (Baumol and Bowen, 1966). When performing arts organisations make qualitative changes in their output due to cost pressures this is referred to as the suppressed form of the cost disease. As a general rule, we expect increasing labour costs to induce a shift within the artistic sector from highly labour intensive productions to less labour intensive productions. The cost disease leads then to a situation where performing arts institutions "debase the product" (Baumol and Baumol, 1985b, 222). They may cut the number of rehearsals, perform in large capacity playhouses, use simpler sets ... in the economically feasible range of (artistic) options. An obvious strategy is to reduce labour costs, since these typically make up for the largest part of total costs. Assuming that wages are more or less fixed, this requires reducing labour input. One 
way to do this is to produce plays with smaller casts. Still, it might be difficult to produce a certain play with fewer actors. In the words of Alan Peacock: "Removing Judge Bouck from the cast of Hedda Gabler would certainly reduce labour input to Ibsen's masterpiece, but it would also destroy the product" (Peacock, 1996, 219). But, of course, a change in the overall composition of the repertoire does make it possible to reduce labour input. Evidence by Baumol and Baumol (1985a; 1985b) shows that this is exactly what happened on Broadway: the average cast size of plays fell from 15,8 to 8,1 between 1946 and 1977. Another cost-saving option that affects the repertoire mix is to choose fewer modern works for which copyright fees have to be paid (Throsby, 1996).

\section{Flemish theatres: 1980-2000}

The Flemish professional theatre sector has gone through remarkable changes in the past decades. As will be shown, the plays that appear on stage today are clearly different from those that were programmed 20 years ago. Our analysis is restricted to those companies that have received 'structural' subsidies from the Flemish community. Altogether these represent the (rather) well-established and professional Flemish theatre sector. In Section 4.1 we describe the output of the Flemish theatres in the period 1980-2000. ${ }^{2}$ Section 4.2 gives the evolution of the theatres' budget. Section 4.3 discusses several hypotheses concerning programmatic choices and the impact of budgetary restrictions. The empirical analysis is in Section 4.4.

\footnotetext{
${ }^{2}$ We consider the seasons 1980-1981 until 2000-2001. In the remainder of this study, theatre seasons will be referred to by the first year mentioned (for example, the season 1993-1994 will be referred to by the year 1993).
} 


\subsection{The description of Flemish theatre output}

To examine the changes in the Flemish theatre output, we describe output at the level of the individual theatres. Rather than focusing on the level of theatre output only, we also account for the heterogeneity of output. Theatre productions differ considerably from one another in many dimensions. Analysing decision-making in the context of the performing arts should explicitly account for such differences (Throsby, 1990). Lancaster's characteristics approach then suggests itself as a tool of analysis (Lancaster, 1966). Following this approach, a theatre production consists of a unique set of $N$ characteristics $z_{i}(i=1, \ldots, \mathrm{N})$ like the language of the play, the period in which the play was written, the number of actors on stage, their identity, and so on:

$$
Z=Z\left\{z_{1}, z_{2}, z_{3}, \ldots, z_{N}\right\}
$$

From the theatre manager's perspective, a programmatic choice on what plays to put on stage corresponds with a choice of specific values for all $z_{i}$. More generally, programmatic choices involve not only the choice of a given play to perform but rather the choice of a set of plays (sets of characteristics) that are performed during a given season along with a decision on how often each given play will be performed,

The Lancasterian characteristics approach has been incorporated into the empirical literature on performing arts attendance. In a demand study of 3 Australian theatre companies, Throsby (1990) includes a variable for repertoire classification. Using dummy variables, plays are classified into four groups according to the date of composition and the familiarity of the playwright. Abbé-Decarroux (1994) estimates the demand for 64 productions of a Swiss theatre company. He classifies the 
repertoire into classic, modern, contemporary and atypical plays based on the date the plays were written and on whether the playwright is a living author or not. Analysing demand for French theatres, Urrutiaguer (2002) divides the repertoire into four categories according to the date of composition, the date of birth and the mother tongue of the playwright. Dummy variables express whether the share of performances programmed by a theatre and belonging to a certain category is $10 \%$ higher than the overall average or not. Corning and Levy (2002) examine demand for performances of the Pacific Conservatory of the Performing Arts. They include indicators for comedies, musicals, and dramas as well as a specific variable for the musical 'Tommy'.

As these studies show, the choice of relevant characteristics to describe output is not straightforward. We identify several characteristics to describe qualitative aspects of individual theatre productions. The following 5 characteristics are considered ${ }^{3}$ :

- $z_{1}$ : the original language of the play

- $z_{2}$ : the age of the playwright

- $z_{3}$ : the fact whether the play is an adaptation ${ }^{4}$ or not

- $z_{4}$ : the number of actors

- $z_{5}$ : the fact whether the production is new or a retake

\footnotetext{
${ }^{3}$ The selection of the characteristics was driven by the literature and the availability of data. Data on programmatic choices come from the 'Vlaamse Theaterjaarboeken' over the period 1980-1998, the database of the 'Vlaams Theater Instituut' and the Flemish Ministry of Culture.

${ }^{4}$ An adaptation is an existing story or play that serves as the source of inspiration for a Flemish author who transforms it in an innovative way
} 
As these characteristics describe individual theatre productions, the relevant description of the program of a theatre for a whole season - a set of productions - can be seen in terms of an aggregation of these characteristics. To describe programmatic choices involving the quantity of output we look at:

- the number of productions

- the number of performances per production.

Werck and Heyndels (2005) show how the choice of repertoire by Flemish theatres changed. Over the period 1980-2000 the share of plays by non-Dutch-speaking authors fell dramatically (from 79 to $26 \%$ of all plays), there was a tendency towards more recent plays and more adaptations. A notable evolution concerns the cast size. Whereas 5,77 actors appeared on stage in the average production in 1980, there are only 4,38 actors per production in 2000. Finally, more productions are being retaken.

The output of the Flemish theatres has also undergone changes in terms of quantity. The average number of productions per theatre increased (from 5,22 in 1980 to 8,04 in 2000) while at the same time the number of performances per production fell (from almost 40 to 20$)$.

\subsection{The evolution of the budgetary situation}

The budget of the Flemish theatres consists of two main sources: structural subsidies of the Flemish Community and own (box-office) income. ${ }^{5}$ The former typically cover

\footnotetext{
${ }^{5}$ Local governments - municipalities and provinces - also subsidize theatres. However, due to the large number of missing data, we did not take these subsidies into account.
} 
between 48 and $52 \%$ of all expenses. Different legislations have regulated the allocation of subsidies. Before 1975, only the large 'repertoire' theatres and a few 'chamber' theatres received subsidies. The 'Theaterdecreet' (Theatre Decree) from 1975 and the 'Podiumkunstendecreet' (Performing Arts Decree) from 1993 shaped the currently existing system. A crucial innovation in the latter Decree is the replacement of the yearly allocation of subsidies by a system of 'structural' subsidies assigned for 4 year-periods. This institutional change was welcomed by the theatres as it facilitated them to plan activities for a number of years without the (financial) uncertainty that was current practice before 1993 (Brouwers, 1994).

The budgetary means of the Flemish theatres fluctuated over the years. After an initial decline in the early 80s the total available budget (subsidies and box office) for all subsidized theatres increased again to a maximum of 23,6 million in 1999 (in prices of 1996). The average theatre budget fluctuated between 650.000 in the early 80s to almost 946.000 in 1999 . Naturally, the evolution in subsidies was largely responsible for these fluctuations: total subsidies fell from over 17,4 million in the early 80 s to 13,4 million in 1986 , after which they started to rise again. Average theatre subsidies were around 572.000 in 1980 and increased to 650.000 for the period 1997-2000.

\section{$\underline{4.3 \text { Budgetary changes and Flemish theatre output }}$}

When making programmatic choices, the theatre manager has to take into account the constraints imposed by the public, by the subsidizing bodies and by its own technology. Depending on the objective(s) of the organisation, different hypotheses on the effect of budgetary changes can be made. A quality-maximising manager could be biased towards a theatre program that is artistically diverse (e.g. with a 
maximum number of different productions). Audience-maximising managers may prefer larger numbers of performances. They may be biased towards more 'popular' plays. ${ }^{6}$ Depending on which objective dominates, there exists a trade-off between the number of productions and the number of performances per production.

By retaking old productions, certain fixed production costs (such as scenery and costumes) can be avoided, and the number of rehearsals can possibly be limited. However, it is a programmatic choice that quality-maximising theatre managers might be reluctant to make, as it does not enhance artistic diversity (Grinwis, 2002). Therefore, we expect such theatre managers to decrease the number of retakes when more budgetary means are available.

It is not straightforward to make a priori assumptions on the evolution of output characteristics under changing budgetary restrictions. The choice of repertoire - and the actors performing it - is one of the most important decisions to be made. Reducing cast size seems an obvious way to reduce labour costs. Hence, a theatre manager may decrease (increase) cast size when confronted with a tightening (expanding) budget. Of course, when a quality-maximising manager regards large productions to be important, he will be reluctant to reduce average cast size. Similarly, an audience-maximising manager will have a preference for large productions if they attract more theatregoers.

\footnotetext{
${ }^{6}$ An audience-maximising manager is indifferent between programming $n$ different plays with each one performance, or performing 1 production $n$ times. Still, as programming a new production has sizeable fixed costs he will perform as few plays as possible (the constraint being that the play has to be popular enough to fill the theatre).
} 
The choice of a play that is contemporary, an adaptation of a classic play or of a play that is written by a Dutch-speaking playwright has less clear-cut budgetary implications. Still, cost-saving measures are possible, e.g. by programming fewer modern works for which copyright fees have to be paid (Throsby, 1996; Baumol and Baumol, 1985b). Again, a quality-maximising theatre manager who regards innovation as indispensable will be less willing to take such a measure.

It is clear that programmatic choices are taken simultaneously. Moreover, decisionmaking is intrinsically interdependent if only because subsidizing bodies take into account (past) programmatic choices as well (Jenkins and Austen-Smith, 1987; Luksetich and Lange, 1995). Politicians who decide on the level of subsidization face a re-election constraint. Therefore they may want to try and avoid drops in popular support. Theatre managers take this into account and will be careful not to provoke politicians, for example by falling short of box office income or by attracting negative publicity (Krebs and Pommerehne, 1995). Demand will also be affected by programmatic choices. Werck and Heyndels (2005) found that Flemish theatre attendance is positively affected by large cast sizes and plays written by Dutchspeaking playwrights. Expectations about consumers' reactions are likely to feed back into the programmatic decision-making, as attendance has a budgetary impact through the box-office.

\section{$\underline{4.4 \text { Empirical analysis }}$}

Responses to budgetary changes are examined using data on all theatres that were subsidized during the period 1980-2000. Our data set consists of an unbalanced panel of 59 theatres. The set of theatres varies over time as some theatres cease to exist, 
others continue to exist but no longer receive structural subsidies, and new theatres are created and subsidized. ${ }^{7}$

To model all aspects of theatre behaviour and to incorporate the simultaneity of decision-making, we estimate a system of simultaneous equations. Quantitative output measures, output characteristics, subsidies, attendance and ticket price are determined simultaneously. Quantitative output measures for theatre $i$ in year $t$ are the number of productions $\left(\mathrm{PROD}_{\mathrm{i}, \mathrm{t}}\right)$ and the number of performances per productions $\left(\mathrm{RUN}_{\mathrm{i}, \mathrm{t}}\right)$. Five output characteristics are taken as dependent variables. CAST $\mathrm{T}_{\mathrm{i}, \mathrm{t}}$ stands for the average cast size of all productions of theatre $i$ in year $t$. INNO for artistic innovation. It corresponds with the proportion of new productions to total productions. $\mathrm{ADAPT}_{\mathrm{i}, \mathrm{t}}$ gives the share of adaptations relative to the number of productions of the company. The dependent variable $\mathrm{AGE}_{\mathrm{i}, \mathrm{t}}$, is a proxy for the age of the plays. It corresponds with the difference between $t$ and the average birth year of the playwrights of all productions of the company. Finally, $\mathrm{DUTCH}_{\mathrm{i}, \mathrm{t}}$ gives the proportion of plays (originally) written in Dutch. These main choice variables of the individual theatres are determined taking into account possible effects on subsidies $\left(\mathrm{SUB}_{\mathrm{i}, \mathrm{t}}\right)$, attendance $\left(\mathrm{Q}_{\mathrm{i}, \mathrm{t}}\right)$ and on the average ticket price charged $\left(\mathrm{P}_{\mathrm{i}, \mathrm{t}}\right)$. Table 1 gives a summary of the system of simultaneous equations.

\section{[Insert Table 1}

about here]

The explanatory variables comprise theatre-specific and market specific determinants. For the latter, a distinction is made between touring and non-touring theatres through a dummy variable, $\mathrm{PLAYH}_{\mathrm{i}, \mathrm{t}}$, which equals 1 when a company is residing in its own 
playhouse and 0 when it is a touring company with no fixed location. The difference between the two types is important since they serve different types of markets. In principle, touring companies can perform in the whole Flemish and Brussels Region. Their 'relevant market' therefore corresponds with the complete set of (308) Flemish and (19) Brussels municipalities. Non-touring companies perform in a playhouse in a particular municipality. Hence, their 'relevant market' is more limited in size. This difference between the two types is accounted for in the definitions of market specific explanatory variables: population size, consumer income and the prices of substitutes: cinema and other theatres' productions.

Population size $\left(\mathrm{POP}_{\mathrm{i}, \mathrm{t}}\right)$ is used as a proxy for the size of the 'relevant market' of theatre company $i$. For touring companies this corresponds with the total population in all Flemish and Brussels municipalities. For non-touring companies the market is geographically limited. It is natural to consider the municipality in which the playhouse resides as part of its 'relevant market'. Still, it is most likely that the market extends beyond the borders of this municipality. Just how far this market extends is an empirical issue. Werck and Heyndels (2005), analyzing demand for Flemish theatres, compare a number of possibilities. They define a 327 x 327 spatial weighting matrix $W$ (Revelli, 2001, 2003). Elements of the matrix, $\mathrm{w}_{\mathrm{jk}}$, equal 1 if municipality $k$ is part of the 'relevant market' for theatre $i$ (located in $j$ ) and 0 otherwise. They find a preferred specification in which $\mathrm{w}_{\mathrm{jk}}=1$ in the municipality where the theatre is located $(j=k)$ as well as in its border sharing municipalities. We use this result for our own analysis. In practical terms, this means that $\mathrm{POP}_{\mathrm{i}, \mathrm{t}}$ for $\mathrm{a}$ non-touring theatre $i$ corresponds to the sum of the population in the municipality where $i$ is located and in its neighbouring municipalities. 
Consumer income $\left(\mathrm{Y}_{\mathrm{i}, \mathrm{t}}\right)$ and the prices of substitutes - cinema ticket price $\left(\right.$ PCINEMA $\left._{i, t}\right)$ and the ticket price of other theatre companies (PSUBTHEA $\left.A_{i, t}\right)$ - are also defined in terms of the 'relevant market'. For touring companies this means that $\mathrm{Y}_{\mathrm{i}, \mathrm{t}}$, PCINEMA $_{\mathrm{i}, \mathrm{t}}$ and PSUBTHEA $_{\mathrm{i}, \mathrm{t}}$ correspond to the average per capita income (weighted by population), the average movie ticket price and the average ticket price of all other theatres in the Flemish and Brussels Region. For non-touring companies, the averages are again calculated for the theatre's own and neighbouring municipalities. $^{8,9}$

Equations (1) to (7) are of central interest. The first two equations have the quantitative output variables as dependent variables. Equations (3) to (7) treat the output characteristics. Each output variable is estimated as a function of its own lag and the theatre's budget (BUDGET $\left.\mathrm{B}_{\mathrm{i}, \mathrm{t}}\right)^{10}$ The budget consists of own (box-office) income and government subsidy. As mentioned, two regimes can be distinguished. Until 1992 subsidies were allocated on a yearly basis. Since then, a 4-year allocation is in use. Responses to budgetary pressures may have changed. To take this into account we interact BUDGET $\mathrm{B}_{\mathrm{i}, \mathrm{t}}$ with a dummy $\mathrm{DS}_{\mathrm{t}}$ that identifies the subsidy regime. $\mathrm{DS}_{\mathrm{t}}=1$ in the years from 1993 onwards (4-year allocation regime) and 0 in the preceding period. ${ }^{11}$

\footnotetext{
${ }^{8}$ The relevant market's income is an average weighted by population.

${ }^{9}$ In practice, movie theatres are only located in (relatively) large municipalities and not in their neighbouring municipalities. Hence, using or not using the spatial weighting matrix makes no difference. Formally, however, the 'relevant market' spreads over to neighbouring municipalities even if in these municipalities no substitute (cinema) is present.

${ }^{10}$ A specification with the lagged value of the budget was estimated as well. The results were similar to those presented in the main text.

${ }^{11}$ Following the current practice in empirical work on political budget cycles, we experimented with alternatives for DS. We defined a variable TUS $_{t}$ which gives the 'time until the following subsidy
} 
Ticket price, subsidy and theatre attendance are determined simultaneously with the programmatic decision variables. Price, $\mathrm{P}_{\mathrm{i}, \mathrm{t}}$, is estimated as a function of attendance in the previous season, $\mathrm{Q}_{\mathrm{i}, \mathrm{t}-1}$, as well as the output variables and consumer income $\mathrm{Y}_{\mathrm{i}, \mathrm{t}}$ (equation 8). Equation 9 examines whether subsidy, $\mathrm{SUB}_{\mathrm{i}, \mathrm{t}}$, is dependent on a theatre's achievements in the previous season. Finally, equation 10 estimates the demand for theatre as a function of ticket price, consumer income, population, the price of cinema and the average price charged by other theatre companies as well as the output characteristics (see Werck and Heyndels, 2005).

The equation system summarized in Table 1 is an over-identified system of simultaneous equations. We use 3-stage least squares as the simultaneous equation method, which yields more efficient results than single equation estimations when the disturbances are correlated across equations. ${ }^{12}$

[Insert Table 2

about here]

round'. So TUS $=0$ in all years before 1993 as well as in 1996 and 2000 (in the latter years decisions are taken on the subsidies for the following 4 years); TUS $_{\mathrm{t}}=1$ in 1995 and 1999, 2 in 1994 and 1998 and 3 in 1993 and 1997. We could not find evidence of a 'budget cycle'.

${ }^{12}$ A Hausman specification test examines the correct system specification, and determines whether 2SLS or 3SLS is the appropriate estimation technique. The results show that a simultaneous equations model is a better estimation technique (2SLS or 3SLS) than a single equation system (OLS), and that the full-information method (3SLS) provides better estimates than a limited-information method (2SLS). 
Table 2 summarises the results. Before turning to the coefficients of central interest (those on BUDGET variables) we briefly discuss the other findings. We restrict ourselves to the results in columns (1) to (7) as these are the main focus of our article. A first observation is that, overall, the lagged variables of the output variables are highly significant, demonstrating that programmatic choices are strongly 'determined' by choices from the past. This reflects that individual theatres have their own specific 'identity' as a result of which artistic choices show stability over time.

A second general finding is the apparent distinction between touring and non-touring (resident) companies. The latter program larger numbers of different productions. This reflects the larger 'relevant' market of the touring companies. Since most theatregoers are not likely to attend the same production more than once, non-touring theatre companies are obliged to offer a 'diverse' program in order to attract potential theatregoers coming from within a certain distance from the playhouse. ${ }^{13}$ As equation 4 shows, the playhouse dummy has a significant and positive effect on innovation: non-touring theatre companies on average program more new productions. This might be explained by their more limited potential audience (smaller 'relevant market'). The proportion of 'Dutch' plays in the program is significantly lower for resident companies. A possible explanation is - again - that they are 'obliged' to present a more diverse program (as their 'relevant market' is smaller) in combination with the fact that the Dutch-language repertoire is limited relative to the overall theatre repertoire.

\footnotetext{
${ }^{13}$ This result seems to be in line with the finding by DiMaggio and Stenberg (1985) for U.S. resident theatres. They find that resident theatres with a larger market have a less 'conformist' repertoire. Of course, diversity as measured by the number of different productions is not the same as 'nonconformity' as measured by DiMaggio and Stenberg's Conformity Index.
} 
Turning to the impact of budgetary changes which are the focus of the current analysis two main conclusions can be drawn. First, we find clear evidence that the theatre's budget has an immediate impact on both the quantity and the nature of the output. Second, the introduction of the 4-year subsidy regime in 1993 has dramatically changed this relationship.

In the pre-1993 period (when subsidies where allocated on a yearly basis) budgetary changes translate into changes in the number of productions and the cast size (equations (1) and (3) respectively). Higher budgets are associated with more artistic diversity as reflected by the increased number of different productions. On the other hand, there is a negative but insignificant relationship between the budget and the average number of performances per production (equation 2). These results suggest that - given sufficient means - theatre managers prefer programming different productions rather than extending the average run of a production. As there is an obvious cost difference between staging a new production and programming an extra performance of an existing production, this result may reflect that Flemish theatre managers maximise quality (defined in terms of programmatic diversity) rather than quantity. Only when forced by the budgetary pressure, the number of productions will be lowered. Negative changes in the budget lead the theatre to lower the number of productions while keeping the average run constant.

Before 1993 the theatre's budgetary situation not only affects the artistic diversity in terms of the quantity of plays. Budgets also have systematic effects on the nature of these plays. Column (3) reveals a highly significant and positive relationship between a theatre's budget and the average cast size of the productions in a given season. Increased budgets are used to expand cast sizes, probably by staging larger 
productions. $^{14}$ As such the evolution on Flemish theatre scenes towards plays with smaller cast sizes (as sketched in section 4.1) can be attributed - at least in part - to budgetary pressures. This structural decline in average cast size in Flemish subsidized theatres is to our knowledge the first confirmation of Baumol and Baumol's (1985a; 1985b) findings on the so-called suppressed cost disease.

Under the yearly subsidy regime though, we find no significant budgetary influence on the proportion of new productions, the choice for contemporary plays, adaptations or plays written by a Dutch-speaking playwright.

After 1993, this situation changes dramatically with the introduction of the 4-yearly subsidies. While the responsiveness of the number of productions to budgetary changes is not significantly affected - also in the post 1993 period higher budgets lead to higher numbers of productions - for all other output variables we find a significant difference with the pre-1993 period. Indeed, the coefficient on the interaction term is significant in equations (2) to (7). First, BUDGET*DS has a negatively significant effect on the number of performances per production (RUN). During the 4-year regime higher budgets translate into less performances per production and (as in the pre-1993 period) into larger numbers of productions. This change in behavior is consistent with the observation that theatre managers work in a financially less risky environment. As they are assured of a sizeable part of their budgets they can 'afford' to take the more costly and (in terms of ticket sales) risky decision to choose for new productions instead of longer runs.

\footnotetext{
${ }^{14}$ Alternatively cast size expansions can reflect the situation where individual actors do no longer play multiple roles within one and the same play. While such a situation is not inexistent in Flemish theatres, it can by no means explain the empirical effect found in table 2 .
} 
Second, a similar change towards more risky programmatic choices may be reflected in the fact that, after 1993, looser budgetary constraints lead theatres to stage more recent plays (equation (6)) and more adaptations (equation (5)). Tighter budgets on the other hand induce (less risky) choices for older and well-established plays that are then performed in their 'original' version.

However, the tendency towards using the budget in order to present an artistically more risky program since the introduction of the 4-yearly subsidy regime is possibly contradicted by the observation in column (4). There we find that larger budgets in the post-1992 period lead to less innovation defined in terms of the share of new productions to retakes. ${ }^{15}$

Finally, column (3) reveals a striking shift in theatres' responses to budgetary changes. Whereas, as discussed, in the pre-1993 period higher budgets translate readily into larger casts, this relation is no longer apparent since the introduction of the four-year regime. While there remains a positive effect (the sum of the coefficients on BUDGET and BUDGET*DS is still significantly positive), it is now much lower. Larger (lower) budgets no longer lead to strong increases (decreases) in the average cast size. A possible explanation is that theatres use additional budgetary means to conform their programmatic choices to the subsidizer's preferences. Before 1993 theatre managers enjoyed relatively less freedom. The subsidizing government made explicit reference to the priority that should be given to (artistic) employment.

\footnotetext{
${ }^{15}$ We have no straightforward explanation for this unless, maybe, that the main incentive to choose for new productions is to convince the subsidizing government to grant (more) subsidies. Indeed, as can be seen from column (9) theatres that are very innovative in these terms systematically receive higher subsidies. This incentive (to convince the subsidizing body) is likely to be smaller under the 4-year subsidy regime.
} 
Theatres received subsidies to spend on wages and general operations. They were obliged to spend minimally $90 \%$ of their personnel expenses on actors and directors that were binded to the theatre by contract. Since 1993 this obligation is no longer present and, given that subsidies are allocated for 4-year periods, this seems to have changed the nature of the theatres' dependence on government subsidies.

\section{Conclusions}

Programmatic choices by theatre managers are not taken in isolation. Decisions on which plays to perform, what actors to attract, how often to perform a given play, ... reflect the objectives pursued by theatre managers and the constraints they face. We analyse how programmatic choices by Flemish subsidized theatres depend on their budgetary constraints. As these (non-profit) theatres depend heavily on government grants, the budgetary constraint not only reflects a dependency on the market but also on the government. Empirically analysing programmatic choices is therefore only possible through estimation of a simultaneous equation system that accounts for this interdependency between theatre managers, the public and the government. We estimate such a model on an (unbalanced) panel of theatres that have received structural subsidies from the Flemish Regional government (over the period 19802000).

We find that theatres' budgets have an impact not only on the number of plays they perform but also on their nature. While indirect, our results offer to our knowledge the first systematic empirical evidence of Baumol's suppressed cost disease. This notion refers to a qualitative change in the artistic output in the performing arts due to relative price changes. 
A crucial observation is that the budgetary impact on programmatic choices depends on the subsidy regime. In the period under consideration, the Flemish government changed the institutional context: until 1992 subsidies were assigned on a yearly basis, since 1993 a 4-yearly subsidy regime came in place. Interestingly, this change in subsidy regime is reflected in the way that theatres respond to budgetary changes. Under the yearly regime changes in a theatre's budget only affect the number of productions (artistic diversity) and the average cast size. Under the 4-yearly regime, budgetary changes have a much more 'general' impact on the nature of the theatrical output: theatres still respond to positive budgetary changes by increasing the number of productions and by increasing cast size (though much less than in the pre-1993 period). At the same time, however, they choose for shorter runs, less innovation, more adaptations and more recent plays and plays written in Dutch. All but the responses in terms of innovation (the share of new productions relative to retakes is actually lowered when theatres are given more budgetary leeway) reflect how theatres in a 4-yearly subsidy regime use additional revenue to make artistically more risky choices. Artistic risk - a choice variable of the individual theatres - substitutes the financial risk which was imposed by the yearly subsidy regime.

\section{References}

Abbé-Decarroux, François (1994) “The Perception of Quality and the Demand of Services. Empirical Application to the Performing Arts." Journal of Economic Behavior and Organisation 23: 99-107.

Austen-Smith, David (1980) "On the Impact of Revenue Subsidies on Repertory Theatre Policy." Journal of Cultural Economics 4: 9-17. 
Baumol, William and Baumol, Hilda (1985a) "The Future of the Theatre and the Cost Disease of the Arts", in Towse, Ruth (ed.), Baumol's Cost Disease. The Arts and other Victims. Edward Elgar, Cheltenham, pp. 195-212.

Baumol, William and Baumol, Hilda (1985b) "On the Cost Disease and its true policy implications for the arts", in Towse, Ruth (ed.), Baumol's Cost Disease. The Arts and other Victims. Edward Elgar, Cheltenham, pp. 213-224.

Baumol, William and Bowen, William (1966) Performing Arts: The Economic Dilemma. A Study of Problems Common to Theater, Opera, Music and Dance. The Twentieth Century Fund, New York.

Brouwers, Toon (1994) "Het Podiumkunstendecreet: Veel geblaat, weinig wol?" Vlaams Theaterjaarboek 1992-93. De Scène, Antwerp, pp. 6-9.

Brouwers, Toon (1998) “De Vlaamse gezelschappen: Terug naar af?" Vlaams Theaterjaarboek. 1996-97 - 1997-98. Vlaams Theater Instituut, Brussels, pp. 1521.

Caves, Richard (2000) Creative Industries: Contracts between Art and Commerce. Harvard University Press, Cambridge.

Corning, Jonathan and Levy, Armando (2002) "Demand for Live Theater with Market Segmentation and Seasonality." Journal of Cultural Economics 26: 217-235.

DiMaggio, Paul (1987) "Nonprofit Organisations in the Production and Distribution of Culture", in Powel, W.W. (ed.), The Nonprofit Organisation. A Research Handbook. Yale University Press, New Haven, pp. 195-220.

DiMaggio, Paul and Stenberg, Kirsten (1985) "Why Do Some Theatres Innovate More than Others? An Empirical Analysis.” Poetics 14: 107-122. 
Du Bois, C., R. Caers, M. Jegers, C. Schepers, S. De Gieter and R. Pepermans (2004) “Agency Problems and unrelated business income of non-profit organizations: an empirical analysis." Applied Economics 36: 2317-2326.

Frey, Bruno and Pommerehne, Werner (1990) “A Comparative Institutional Analysis in the Arts: the Theatre", in Towse, Ruth (ed.), Cultural Economics: The Arts, the Heritage and the Media Industries. Volume II. Edward Elgar, Cheltenham, pp. 483-498.

Grinwis Plaat Stultjes, Mona (2002) "Vernieuwing in de podiumkunsten. Een verkennend onderzoek." Nieuw Tijdschrift van de VUB 15(1): 119-135.

Hansmann, Henry (1981) "Nonprofit Enterprise in the Performing Arts." Bell Journal of Economics 12 (2): 341-361.

Heilbrun, James (2001) "Empirical Evidence of a Decline in Repertory Diversity among American Opera Companies 1991/92 to 1997/98." Journal of Cultural Economics 25: 63-72.

Jenkins, Stephen and Austen-Smith, David (1987) "Interdependent Decision-Making in Non-Profit Industries. A Simultaneous Equation Analysis of English Provincial Theatre.” International Journal of Industrial Organization 5: 149-174.

Krebs, Susanne and Pommerehne, Werner W. (1995) "Politico-Economic Interactions of German Public Performing Arts Institutions.” Journal of Cultural Economics 19: $17-32$.

Lancaster, Kelvin (1966) “A New Approach to Consumer Theory." Journal of Political Economy 74(2): 132-157.

Le Pen, Claude (1982) “L'analyse microéconomique de la production dramatique et l'effet des subventions publiques." Revue économique 4: 639-674. 
Luksetich, William A. and Lange, Mark D. (1995) “A Simultaneous Model of Nonprofit Symphony Orchestra Behavior.” Journal of Cultural Economics 19: 49-68.

Martorella, Rosanne (1975) "The Structure of the Market and Musical Style. The Economics of Opera Production and Repertoire: An Exploration.” International Review of the Aesthetics and Sociology of Music 6(2): 241-254.

Niskanen, William A. (1971) Bureaucracy and Representative Government. Aldine Atherton, Chicago.

O’Hagan, John, and Neligan, Adriana (2005) "State Subsidies and Repertoire Conventionality in the Non-profit English Theatre Sector: An Econometric Analysis.” Journal of Cultural Economics 29: 35-57.

Peacock, Alan (1996) "The "Manifest Destiny" of the Performing Arts." Journal of Cultural Economics 20: 215-224.

Pierce, Lamar J. (2000) "Programmatic Risk-Taking by American Opera Companies." Journal of Cultural Economics 24: 45-63.

Revelli, Frederico (2001) "Spatial patterns in local taxation: tax mimicking or error mimicking?"Applied Economics 33: 1101-1107.

Revelli, Federico (2003) "Reaction or Interaction? Spatial Process Identification in Multi-tiered Government Structures.” Journal of Urban Economics 53: 29-53.

Throsby, David (1990) "Perception of quality in demand for the theatre." Journal of Cultural Economics 14(1): 65-82.

Throsby, David (1996) "Economic Circumstances of the Performing Artist: Baumol and Bowen Thirty Years On.” Journal of Cultural Economics 20: 225-240.

Urrutiaguer, Daniel (2002) "Quality judgements and demand for French public theatre." Journal of Cultural Economics 22: 185-2002. 
Werck, Kristien and Heyndels, Bruno (2005) "Programmatic Choices and the Demand for Theatre: The Case of Flemish Theatres." Working paper, Vrije Universiteit Brussel, Brussels. 


\section{Table 1: Simultaneous equations model}

\section{Quantity of output supplied}
(1) Productions
(2) Performances per production

PROD $_{\mathrm{i}, \mathrm{t}}=f\left(\mathrm{PROD}_{\mathrm{i}, \mathrm{t}-1}, \mathrm{BUDGET}_{\mathrm{i}, \mathrm{t}}, \mathrm{BUDGET}_{\mathrm{i}, \mathrm{t}} * \mathrm{DS}_{\mathrm{t}}, \mathrm{PLAYHi}_{\mathrm{t}}\right)$

$\mathrm{RUN}_{\mathrm{i}, \mathrm{t}}$

$=f\left(\mathrm{RUN}_{\mathrm{i}, \mathrm{t}-1}, \mathrm{BUDGET}_{\mathrm{i}, \mathrm{t}}, \mathrm{BUDGET}_{\mathrm{i}, \mathrm{t}} * \mathrm{DS}_{\mathrm{t}}, \mathrm{PLAYH}_{\mathrm{i}, \mathrm{t}}\right)$

\section{Output characteristics}

(3) Average cast size

(4) Innovation (proportion of new productions)

CAST $_{\mathrm{i}, \mathrm{t}}=f\left(\mathrm{CAST}_{\mathrm{i}, \mathrm{t}-1}, \mathrm{BUDGET}_{\mathrm{i}, \mathrm{t}}, \mathrm{BUDGET}_{\mathrm{i}, \mathrm{t}} * \mathrm{DS}_{\mathrm{t}}, \mathrm{PLAYH}_{\mathrm{i}, \mathrm{t}}\right)$

(5) Proportion of adaptations

(6) Average age of the playwrights

INNO $_{\mathrm{i}, \mathrm{t}}=f\left(\mathrm{INNO}_{\mathrm{i}, \mathrm{t}-\mathrm{l}}, \mathrm{BUDGET}_{\mathrm{i}, \mathrm{t}}, \mathrm{BUDGET}_{\mathrm{i}, \mathrm{t}} * \mathrm{DS}_{\mathrm{t}}, \mathrm{PLAYH}_{\mathrm{i}, \mathrm{t}}\right)$

ADAPT $_{\mathrm{i}, \mathrm{t}}=f\left(\mathrm{ADAPT}_{\mathrm{i}, \mathrm{t}-1}, \mathrm{BUDGET}_{\mathrm{i}, \mathrm{t}}, \mathrm{BUDGET}_{\mathrm{i}, \mathrm{t}} * \mathrm{DS}_{\mathrm{t}}, \mathrm{PLAYH}_{\mathrm{i}, \mathrm{t}}\right)$

$\mathrm{AGE}_{\mathrm{i}, \mathrm{t}}=f\left(\mathrm{AGE}_{\mathrm{i}, \mathrm{t}-1}, \mathrm{BUDGET}_{\mathrm{i}, \mathrm{t}}, \mathrm{BUDGET}_{\mathrm{i}, \mathrm{t}} * \mathrm{DS}_{\mathrm{t}}, \mathrm{PLAYH}_{\mathrm{i}, \mathrm{t}}\right)$

DUTCH $_{\mathrm{i}, \mathrm{t}}=f\left(\mathrm{DUTCH}_{\mathrm{i}, \mathrm{t}-1}, \mathrm{BUDGET}_{\mathrm{i}, \mathrm{t}}, \mathrm{BUDGET}_{\mathrm{i}, \mathrm{t}}\right.$ DUS $\left._{\mathrm{t}}, \mathrm{PLAYH}_{\mathrm{i}, \mathrm{t}}\right)$

\section{Price}

7 (8) Price

$$
\mathrm{P}_{\mathrm{i}, \mathrm{t}}
$$
Government subsidy

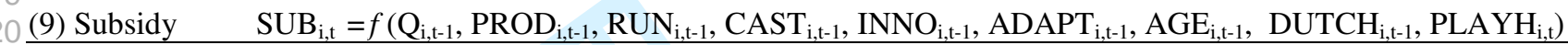

\section{Consumer demand}

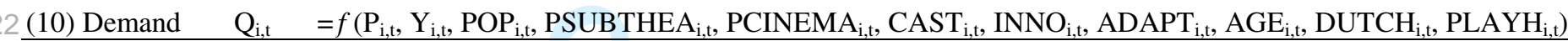


Table 2: 3SLS estimation results

\begin{tabular}{|c|c|c|c|c|c|c|c|c|c|c|}
\hline \multirow{2}{*}{$\begin{array}{l}\text { Independent } \\
\text { variables }\end{array}$} & \multicolumn{10}{|c|}{ Dependent variables } \\
\hline & $\begin{array}{l}\text { Prod } \\
\text { (1) }\end{array}$ & $\begin{array}{l}\text { Run } \\
\text { (2) }\end{array}$ & $\begin{array}{l}\text { Cast } \\
\text { (3) }\end{array}$ & $\begin{array}{l}\text { Inno } \\
\text { (4) }\end{array}$ & $\begin{array}{l}\text { Adapt } \\
\text { (5) }\end{array}$ & $\begin{array}{l}\text { Age } \\
(6)\end{array}$ & $\begin{array}{l}\text { Dutch } \\
\text { (7) }\end{array}$ & $\begin{array}{l}\mathbf{P} \\
(8)\end{array}$ & $\begin{array}{l}\text { Sub } \\
(9)\end{array}$ & $\begin{array}{l}Q \\
(10)\end{array}$ \\
\hline Constant & $\begin{array}{l}1,38 * * * \\
(6,24)\end{array}$ & $\begin{array}{l}17,64 * * * \\
(10,95)\end{array}$ & $\begin{array}{l}1,71 * * * \\
(9,05)\end{array}$ & $\begin{array}{l}0,46 * * * \\
(13,44)\end{array}$ & $\begin{array}{l}0,06 * * * \\
(3,99)\end{array}$ & $\begin{array}{l}78,98 * * * \\
(7,83)\end{array}$ & $\begin{array}{l}0,24 * * * \\
(7,60)\end{array}$ & $\begin{array}{l}0,63 \\
(0,13)\end{array}$ & $\begin{array}{l}-0,06 \\
(-0,78)\end{array}$ & $\begin{array}{l}78,09 \\
(0,58)\end{array}$ \\
\hline $\operatorname{Prod}_{-1}$ & $\begin{array}{l}0,65 * * * \\
(18,46)\end{array}$ & & & & & & & & $\begin{array}{l}0,01 * * \\
(2,46)\end{array}$ & \\
\hline Run $_{-1}$ & & $\begin{array}{l}0,44 * * * \\
(12,25)\end{array}$ & & & & & & & $\underset{(-4,05)}{-4,01 \mathrm{E}-03 * * *}$ & \\
\hline Cast $_{-1}$ & & & $\begin{array}{l}0,46 * * * \\
(10,43)\end{array}$ & & & & & & $\begin{array}{l}0,04 * * * \\
(8,45)\end{array}$ & \\
\hline Inno.-1 $_{-1}$ & & & & $\begin{array}{l}0,31 * * * * \\
(7,02)\end{array}$ & & & & & $\begin{array}{l}0,23 * * * \\
(4,64)\end{array}$ & \\
\hline Adapt $_{-1}$ & & & & & $\begin{array}{l}0,33 * * * \\
(7,62)\end{array}$ & & & & $\begin{array}{l}0,07 \\
(1,07)\end{array}$ & \\
\hline Age $_{-1}$ & & & & & & $\begin{array}{l}0,11 * * * \\
(2,70)\end{array}$ & & & $\underset{(1,91)}{1,85 \mathrm{E}-04 *}$ & \\
\hline Dutch $_{-1}$ & & & & & & & $\begin{array}{l}0,54 * * * \\
(14,47)\end{array}$ & & $\begin{array}{l}-3,47 \mathrm{E}-03 \\
(-0,09)\end{array}$ & \\
\hline Budget & $\begin{array}{l}0,68 * * \\
(2,32)\end{array}$ & $\begin{array}{l}-0,17 \\
(-0,11)\end{array}$ & $\begin{array}{l}1,80 \text { **** } \\
(5,93)\end{array}$ & $\begin{array}{l}1,55 \mathrm{E}-03 \\
(0,06)\end{array}$ & $\begin{array}{l}-2,44 \mathrm{E}-03 \\
(-0,12)\end{array}$ & $\begin{array}{l}20,62 \\
(1,50)\end{array}$ & $\begin{array}{l}-0,03 \\
(-0,81)\end{array}$ & & & \\
\hline Budget $*$ DS & $\begin{array}{l}0,20 \\
(0,81)\end{array}$ & $\begin{array}{l}-3,53 * * \\
(-2,43)\end{array}$ & $\begin{array}{l}-1,01 * * * \\
(-4,64)\end{array}$ & $\begin{array}{l}-0,07 * * * \\
(-2,60)\end{array}$ & $\begin{array}{l}0,06 * * * \\
(2,87)\end{array}$ & $\begin{array}{l}-45,15 * * * \\
(-3,58)\end{array}$ & $\begin{array}{l}0,16 * * * * \\
(5,05)\end{array}$ & & & \\
\hline Playh & $\begin{array}{l}0,68 * * \\
(2,44)\end{array}$ & $\begin{array}{l}0,05 \\
(0,03)\end{array}$ & $\begin{array}{l}0,07 \\
(0,31)\end{array}$ & $\begin{array}{l}0,10 * * * \\
(3,48)\end{array}$ & $\begin{array}{l}-0,01 \\
(-0,53)\end{array}$ & $\begin{array}{l}17,25 \\
(1,24)\end{array}$ & $\begin{array}{l}-0,12 * * * \\
(-3,45)\end{array}$ & $\begin{array}{l}0,28 \\
(0,31)\end{array}$ & $\begin{array}{l}0,25 * * * \\
(8,36)\end{array}$ & $\begin{array}{l}-141,95 \\
(-1,16)\end{array}$ \\
\hline$Q_{-1}$ & & & & & & & & $\begin{array}{l}-0,12 * * * \\
(-8,39)\end{array}$ & $\underset{(9,04)}{5,25 \mathrm{E}-03 * * *}$ & \\
\hline Prod & & & & & & & & $\begin{array}{l}0,22 \\
(1,52)\end{array}$ & & \\
\hline Run & & & & & & & & $\begin{array}{l}0,09 * * \\
(2,05)\end{array}$ & & \\
\hline Cast & & & & & & & & $\begin{array}{l}1,20 * * * \\
(5,06)\end{array}$ & & $\begin{array}{l}7,50 * * * \\
(3,59)\end{array}$ \\
\hline Inno & & & & & & & & $\begin{array}{l}-11,28 * * * \\
(-2,93)\end{array}$ & & $\begin{array}{l}-56,87 \\
(-1,43)\end{array}$ \\
\hline Adapt & & & & & & & & $\begin{array}{l}8,32 * \\
(1,92)\end{array}$ & & $\begin{array}{l}50,73 \\
(1,06)\end{array}$ \\
\hline Age & & & & & & & & $\begin{array}{l}-2,07 \mathrm{E}-03 \\
(-0,12)\end{array}$ & & $\begin{array}{l}0,07 \\
(0,38)\end{array}$ \\
\hline Dutch & & & & & & & & $\begin{array}{l}-1,09 \\
(-0,45)\end{array}$ & & $\begin{array}{l}-14,85 \\
(-0,55)\end{array}$ \\
\hline $\mathbf{P}$ & & & & & & & & & & $\begin{array}{l}-12,30 * * * \\
(-5,52)\end{array}$ \\
\hline $\mathbf{Y}$ & & & & & & & & $\begin{array}{l}9,66 \mathrm{E}-04 * * * \\
(3,05)\end{array}$ & & $\begin{array}{l}0,02 * * * \\
(4,25)\end{array}$ \\
\hline Pop & & & & & & & & & & $\begin{array}{l}-0,02 \\
(-1,09)\end{array}$ \\
\hline Pcinema & & & & & & & & & & $\begin{array}{l}10,08 \\
(1,44)\end{array}$ \\
\hline Psubthea & & & & & & & & & & $\begin{array}{l}-1,13 \\
(-0,40)\end{array}$ \\
\hline $\mathbf{R}^{2}$ & 0,60 & 0,19 & 0,60 & 0,15 & 0,11 & 0,05 & 0,41 & 0,08 & 0,73 & 0,18 \\
\hline
\end{tabular}

Notes: t-values in parentheses, $* * *$ significant at $1 \%, * *$ at $5 \%, *$ at $10 \%$;

Q, Q-1 and Pop in (.000); Sub and Budget in (.000 000). 